\title{
Association of Peptic Ulcer Diseases with Helicobacter Pylori Infection in Iraqi Patients
}

\author{
Essmaa H. Gutef \\ Department of Basic Science, Collage of Dentistry, Wasit University, Iraq.
}

\begin{abstract}
Objective: To determine the prevalence of Helicobacter pylori (H. pylori) infection among patients presenting with peptic ulcer disease (PUD). We aimed to examine the effect of age, gender, and types of peptic ulcer on the prevalence of the disease.

Methods: The study included 75 patients with PUD who underwent upper gastrointestinal endoscopy at Baghdad Teaching Hospital/Medical City from 1st of February to 30st of June 2015. All patients underwent upper gastrointestinal endoscopy for visual examination to distinguish between the gastric ulcer (GU) and duodenal ulcer (DU), and the stool antigen test (SAT) for the detection of $H$. pylori.

Results: The overall prevalence rate of $H$. pylori infection among 75 patients with PUD was $71.3 \%$, while it was high among males $(54.55 \%)$ as compared with females (45.45\%). The $H$. pylori was high among males predominance with duodenal ulcer (56.1\%) as compared with females (43.9),also high incidence of gastric ulcer was shown in this study in elderly patients with mean age $(50.4 \pm 3.07)$ years, compared to that of duodenal ulcers mean age $(34.5 \pm 2.69)$. Considering the location of ulcer, a lower prevalence of $H$. pylori infection was found in patients with gastric ulcer, at a rate of $66.7 \%$, compared with $75.9 \%$ for those with duodenal ulcers.
\end{abstract}

\section{INTRODUCTION}

Helicobacter pylori are Gram negative bacillus, motile, flagellated and spiral shape bacteria that appears to inhabit the mucous layer overlying the gastric epithelial cells in humans ${ }^{1}$. Around $90 \%$ of DU patients and $70 \%$ of GU patients are infected with $\mathrm{H}$. pylori; the remaining $30 \%$ of $\mathrm{GU}$ are due to NSAIDs². it may cause variety of clinical symptoms such as chronic gastritis of varying severity in infected subjects, which in around $10-15 \%$ progresses to peptic ulcer, while in 1-2\% of subjects ultimately results in mucosa associated lymphoid tissue (MALT) lymphoma or gastric adenocarcinoma ${ }^{3,4}$.

The initial response to infection is an interaction of the host epithelial cells with the bacteria ${ }^{5}$. The majority of $H$. pylori infected persons are asymptomatic, and only a fraction (10-20\%) of carriers' manifests clinical disease. , $^{6,7}$

In 1983, Warren and Marshall described the presence of curved bacilli on gastric epithelia taken from patient with active chronic gastritis and later on it have been proved that H.pylori are responsible for many gastrointestinal tract diseases including peptic ulcer. ${ }^{8}$

A peptic ulcer can be defined as a form of ulceration which develops for a reason in the epithelial lining surface expose to acid secretion of gastric glands. ${ }^{9}$
Conclusion: The high prevalence of $H$. pylori with gastric ulcer was found in the elderly and the high prevalence of $H$. pylori with duodenal ulcer was found in the males, also a lower prevalence of $H$. pylori infection was found in patients with gastric ulcer compared with those with duodenal ulcers.

Keywords: Gastroduodenal diseases, Helicobacter pylori, Peptic ulcer, Iraq.

\section{${ }^{*}$ Correspondence to:}

Essmaa H. Gutef, Department of Basic Science, Collage of Dentistry, Wasit University, Iraq.

Email: asmaahussain40@yahoo.com

\section{Article History:}

Received: 22-05-2016, Revised: 24-05-2016, Accepted: 30-05-2016

\begin{tabular}{|l|c|}
\hline \multicolumn{2}{|c|}{ Access this article online } \\
\hline Website: & Quick Response code \\
www.jimrp.com & \\
\hline DOI: & \\
10.21276/ijmrp.2016.2.3.053 & \\
\hline
\end{tabular}

\section{MATERIALS AND METHODS}

This study performs on newly diagnosed patients with peptic ulcer disease, who attended the Endoscopy Unit of Baghdad Teaching Hospital/Medical City from 1st of February to 30st of June 2015. Patients were selected by a senior physician. Exclusion criteria if they were treated with antibiotics, proton pump inhibitors (ppls) for the last 2 weeks, $\mathrm{H} 2$ receptor blockers, bismuth salts, and diarrhea at the time of sampling. Based on endoscopic examination patients were classified into the following groups: gastric ulcer $(n=14)$, duodenal ulcer $(n=41)$ and Stool specimens from each patient were collected and kept on $-20^{\circ} \mathrm{C}$ until used for detection of $H$. pylori by SAT.

\section{Diagnosis of PUD}

The endoscopic examination was performed to verify the diagnosis of peptic ulcer disease distinguish between the gastric ulcer and duodenal ulcer.

\section{Identification of $\boldsymbol{H}$. pylori}

Stool antigen test (SAT) identifies H.pylori antigen present in Stool. It's based immuno-chromatographic assay by a test kit (Helicobacter Antigen Quick Castte, Bucharest, Romania). Allow the test castte and samples to reach room temperature prior to testing. Place $1 \mathrm{ml}$ (approximately 20 drops) of the sample 
diluents in a test tube. Add approximately a sample portion of 5 $\mathrm{mm}$ diameter with a swab and shake gently in order to unstick and facilitate the sample dispersion. Shake the test tube well in order to assure good sample dispersion. Let the tube rest for at least 5 min for sedimentation. Dispense 4 drops of clear supernatant into the sample well of the cassette. Read the result after 10-15 minutes. In case of positive result colored line might existed, while its lack indicated a negative result.

\section{Statistical Analysis}

Data were analyzed using SAS 2012 (Statistical Analysis System). Chi-square test was utilized to compare between the results of the studied parameters among different patients groups [10). Values with $\mathrm{P}<0.05$ were considered to be significant.

\section{RESULTS}

A total 75 patients with endoscopically proved peptic ulcer were include in this study. fivety-five patients were H.pylori positive, 30
(54.55\%) were male and 25 (45.45\%) were female, patient with gender have significant difference ${ }^{*}(P<0.05)$. Twenty were $H$. pylori negative, $10(50 \%)$ were male and $10(50 \%)$ were female as shown in table 1.

The age of 14 patients with gastric ulcer range from $42-70$ years (mean $=50.4 \pm 3.07)$, 7 male $(50 \%)$ and 7 females $(50 \%)$ while the ages of 41 patients with duodenal ulcer range from 30-70 years (mean=34.5 \pm 2.69 ), 23 male $(56.1 \%)$ and 18 female (43.9\%) as shown in table 2.

The prevalence of H.pylori infection that determined by SAT shows that $55(73.3 \%$ ) were H.pylori positive while $20(26.7 \%)$ of the patients were $H$. Pylori negative. patients with gastric ulcer high significant difference $(\mathrm{P}<0.01)$ in prevalence between H.pylori positive $(66.7 \%)$ and H.pylori negative (33.3\%).patients with duodenal ulcer have high significant difference $(P<0.01)$ in prevalence between H.pylori positive $(75.9 \%)$ and H.pylori negative $(24.1 \%)$ respectively as shown in table 3.

Table 1: Distribution of H.pylori positive and negative in patients with peptic ulcer disease according to gender

\begin{tabular}{lccccc}
\hline \multirow{2}{*}{ Gender } & \multicolumn{5}{c}{ SAT } \\
\cline { 2 - 6 } & $\mathrm{N}$ & $\%$ & $\mathrm{~N}$ & \multicolumn{1}{c}{ (H.pylori-ve) } & Total \\
Male & 30 & $54.55 \%$ & 10 & $50.00 \%$ & 40 \\
Female & 25 & $45.45 \%$ & 10 & $50.00 \%$ & 35 \\
Total & 55 & & 20 & & 75 \\
Chi-square & $4.68^{*}$ & & $00.0 \mathrm{NS}$ & $3.25 \mathrm{NS}$ \\
\hline \multicolumn{1}{c}{${ }^{*}(\mathrm{P}<0.05)$} & & &
\end{tabular}

Table 2: Age and gender distribution in peptic ulcer patients infected with H.pylori according to the type of ulcer

\begin{tabular}{lccccc}
\hline Ulcer type & Patients number & \multicolumn{2}{c}{ Age } & \multicolumn{2}{c}{ Gender } \\
\cline { 3 - 6 } & & Range & Mean & Male & Female \\
Gastric ulcer & 14 & $42-70$ & $50.4 \pm 3.07$ & $7(50.00 \%)$ & $\mathbf{7 ( 5 0 . 0 0 \% )}$ \\
Duodenal ulcer & 41 & $30-70$ & $34.5 \pm 2.69$ & $23(56.1 \%)$ & $\mathbf{1 8 ( 4 3 . 9 \% )}$ \\
Total & 55 & $30-70$ & $36.6 \pm 2.75$ & $30(53.1 \%)$ & $\mathbf{2 5 ( 4 6 . 9 \% )}$ \\
\hline
\end{tabular}

Data presented as mean $\pm \mathrm{SE}$ (age)

Data presented as number and percentage (\%)

Table 3: Prevalence of $H$.pylori infection in patients with peptic ulcer disease

\begin{tabular}{|c|c|c|c|c|c|c|}
\hline \multirow[t]{2}{*}{ Ulcer type } & \multirow{2}{*}{$\begin{array}{l}\text { Patients } \\
\text { number }\end{array}$} & \multicolumn{2}{|c|}{ Positive result } & \multicolumn{2}{|c|}{ Negative result } & \multirow[t]{2}{*}{ Chi- square } \\
\hline & & $\mathbf{N}$ & $\%$ & $\bar{N}$ & $\%$ & \\
\hline Gastric ulcer & 21 & 14 & $(66.7 \%)$ & 7 & $(33.3 \%)$ & $10.673^{* *}$ \\
\hline Duodenal ulcer & 54 & 41 & $(75.9 \%)$ & 13 & $(24.1 \%)$ & $12.094^{* *}$ \\
\hline Total & 75 & 55 & $(71.3 \%)$ & 20 & $(28.7 \%)$ & $10.827^{* *}$ \\
\hline
\end{tabular}

\section{DISCUSSION}

Helicobacter pylori (H. pylori) infection is a worldwide problem with a significant morbidity and mortality. ${ }^{11,12}$ Since the discovery of $H$. pylori, several studies have been undertaken to evaluate the prevalence of $H$.pylori among gastroduodenal manifestations.

Regarding the gender, male and female for $H$. pylori positive patients were (30 males and 25 females), this finding was close to that of Hajiani et al., $(2008)^{13}$ regarding $H$. pylori positivity, where male gender showed only a marginal predominance. ${ }^{13} \mathrm{~A}$ study by Yasir et al., (2014) ${ }^{14}$ was found the predominance of male gender over female in $\mathrm{H}$. Pylori positive patients. ${ }^{14}$ This may be due to a significant higher infection rates in men than women and the literatures regarding the relationship between sex and $H$. pylori infection is conflicting. It is possible that women are more likely to have infection eradicated with antimicrobials used for other illnesses. ${ }^{15}$ The result in this study showed a male predominance with DU in $\mathrm{H}$. pylori positive patients and this finding was in agreement with Marques et al., (2011) $)^{16}$ who reported a high prevalence of duodenal ulcer in a male gender of Brazilian population with positive $H$. pylori infection. This was considered important determinants to gastrointestinal diseases outcome.16 Chao Wu et al., (2008)17 also reported a markedly lower prevalence of duodenal ulcer in females than in males.

Studies had also reported a lower incidence of duodenal ulcer in young women until the onset of menopause and led to the idea that somehow female hormones protect against the development of duodenal ulcer. ${ }^{18,19}$ Tuo et al., (2011) ${ }^{20}$, conclude that estrogen regulates human duodenal bicarbonate secretion, which could reduce the risk for duodenal ulcer in women and contribute to sex differences in prevalence of duodenal ulcer. ${ }^{20}$ 
A relatively high incidence of gastric ulcer was shown in this study in elderly people with mean age $(50.4 \pm 3.07)$ years, compared to that of duodenal ulcers mean age $(34.5 \pm 2.69)$ years, which was consistent with Dong et al., (2004) ${ }^{21}$ who reported an older patients with gastric ulcer than with duodenal ulcer. ${ }^{21}$ This may be attributable to lower defensive factors such as poor gastrin action capable of healing by its atrophic effect, decreased mucus, bicarbonate secretion and prostaglandins. ${ }^{16}$

In this study $73.3 \%$ of peptic ulcer patients were positive for $\mathrm{H}$. pylori and $26.7 \%$ were negative. This was consistent with other studies reported higher percentage of $H$. pylori positive $(69.3 \%$ $80.4 \%)$ compared to $(19.6 \%-30.7 \%) \quad H$. pylori negative patients. ${ }^{14,22}$

In one study conducted in Iraq showed that $78 \%$ of adults were infected with $\mathrm{H}$. pylori. ${ }^{23}$ Considering the prevalence duodenal and gastric ulcers in $H$. pylori infected patients of in this study we found a higher prevalence of duodenal and gastric ulcers in $H$. pylori infected patients than in patients without $H$. pylori infection. Similar results were also reported by Chao Wu et al., (2008)..17 This may indicate the role of $H$. Pylori infection was the main environmental risk factor in patients with gastric ulcer and duodenal ulcer. ${ }^{24}$

\section{CONCLUSION}

According to the data obtained during this study we can conclude that considering the location of ulcer, a lower prevalence of $H$. pylori infection was found in patients with gastric ulcer, at a rate of $66.7 \%$, compared with $75.9 \%$ for those with duodenal ulcers. This finding was in agreement with other studies.25,26 Also comparable results of other studies reported $H$. pylori infection in about (42.9\%-70\%) in cases with gastric ulcers and (62.4\%-90\%) in those with duodenal ulcers. ${ }^{27,28}$

\section{REFERENCES}

1. Engstrand $L$ and Lindberg $M$. Helicobacter pylori and the gastric microbiota. Best Pract Res Clin Gastroenterol 2013; 27(1): $39-45$.

2. Martins LC, de Oliveira Corvelo TC, Oti HT, et al. ABH and Lewis antigen distributions in blood, saliva and gastric mucosa and $\mathrm{H}$ pylori infection in gastric ulcer patients. World J Gastroenterol 2006; 12(7): 1120-4.

3.Kumar S, Kumar A, Dixit VK. Direct detection and analysis of vacA genotypes and cagA gene of Helicobacter pylori from gastric biopsies by a novel multiplex polymerase chain reaction assay. Diagn Microbiol Infect Dis 2008;62:366-73.

4.Forsyth MH, Atherton JC, Blaser MJ, Cover TL. Heterogeneity in levels of vacuolating cytotoxin gene ( $\mathrm{vacA})$ transcription amongHelicobacter pylori strains. Infect Immun 1998;66:3088-94.

5. Calvino-Fernández M and Parra-Cid T. H. pylori and mitochondrial changes in epithelial cells. The role of oxidative stress. Revista Española de Enfermedades Digestivas 2010; 102(1): 41-50

6. Calvino-Fernández M and Parra-Cid T. H. pylori and mitochondrial changes in epithelial cells. The role of oxidative stress. Revista Española de Enfermedades Digestivas 2010; 102(1): 41-50

7.Yamaota Y, Kato M, Asaka M. Geographic differences in gastric cancer incidence can be explained by differences betweenHelicobacter pylori strains. Intern Med 2008;47:1077-83.

8.Pahwa R, Neeta, Kumar V, Kohli K. Clinical manifestations, causes and management strategies of peptic ulcer disease. Int .J .Pharm .Sci. Drug . Res . 2010; 2(2): 99-106.

9. Friedman S L, McQuaid K R, Grendell J H. Current Diagnosis \& Treatment in Gastroenterology 2nd ed. McGraw-Hill/Appleton \& Lange ; 2002. p 569-597.
10. SAS. 2012. Statistical Analysis System, User's Guide. Statistical. Version 9.1th ed. SAS. Inst. Inc. Cary. N.C. USA.

11. Fuccio L, Eusebi LH \& Bazzoli F. Gastric cancer, Helicobacter pylori infection and other risk factors. WorldJGastrointest Oncol.2010;2: 342-7.

12. Alakkari A, Zullo Aand O'Connor HJ. Helicobacter pylori and nonmalignant diseases. Helicobacter 2011; 16 (1): 33-37.

13. Hajiani e, hashemi $j$ and vosoghi t. comparison of a 10 day triple and a two-week quadruple therapy in eradicating helicobacter pylori infection in patients referred to imam khomeini hospital clinics ahwaz, iran. jundishapur journal of natural pharmaceutical products 2008; 3(1): 45-52.

14. Yasir S, Moin F and Akhtar S M.Frequency of Helicobacter Pylori Infection on Histopathology in Patients with Dyspepsia. American Journal of Clinical Medicine Research 2014; 2 ( 3): 53-56.

15. Naja $\mathrm{F}$, Kreiger $\mathrm{N}$ and Sullivan $\mathrm{T}$. Helicobacter pylori infection in Ontario: Prevalence and risk factors. Can. J. Gastroenterol . $2007 ; 21$ (8): 501-506.

16. Marques SB, Mattar R, Artifon EL, et al. High prevalence of duodenal ulcer in a tertiary care hospital in the city of São Paulo, SP, Brazil. Arq. Gastroenterol 2011; 48 (3): 171-174.

17. Chao Wu H, Guang Tuo B, Min Wu W, et al. Prevalence of Peptic Ulcer in Dyspeptic Patients and the Influence of Age, Sex, and Helicobacter pylori Infection, Digestive diseases and sciences 2008; 53(10): 2650-2656.

18. Javed M, Amin K, Muhammad D,et al. Prevalence of $H$. Pylori. Professional Med. J. 2010; 17 (3): 431-439

19. Andrecia V, Dumitras D, Sasca N, et al. H. Pylori like organisms in gastrodoudenal disease. Gastroenterol. Clin. Biol. 1990; 14 (5): 437-41.

20. Tuo B , Wen $G$ and Wei J. Estrogen Regulation of Duodenal Bicarbonate Secretion and Sex-Specific Protection of Human Duodenum, Gastroenterology 2011; 141 (3): 854-863.

21. Dong WG, Cheng CS, Liu SP, et al. Epidemiology of peptic ulcer disease in Wuhan area of China from 1997 to 2002. World J. Gastroenterol .2004; 10 (22): 3377-3379.

22. Nwodo E.N, Yakubu S.E ,Jatau E.D ,et al. Seroprevalence of Helicobacter pylori Infection in Patients with Gastritis and Peptic Ulcer Disease in Kaduna, Kaduna State, Nigeria. African Journal of Basic \& Applied Sciences 2009; 1 (5-6): 123-128.

23. Hussein NR, Robinson $\mathrm{K}$, Atherton JC et al. A study of age specific $\mathrm{H}$ pylori seropositivity rates in Iraq. Helicobacter 2008; 13(4): 306-7.

24. Barazandeh F, Yazdanbod A, Pourfarzi F, et al. Epidemiology of Peptic Ulcer Disease: Endoscopic Results of a Systematic Investigation in Iran. Middle East J. Dig. Dis . 2012; 4 (2): 90-96.

25. Rosenstock $S$, J $\tilde{A}_{s}$ rgensen T, Bonnevie O, et al. Risk factors for peptic ulcer disease: a population based prospective cohort study comprising 2416 Danish adults. Gut .2003; 52 (2): 186-193.

26. Ciociola AA, McSorley DJ, Turner K, et al. Helicobacter pylori infection rates in duodenal ulcer patients in the United States may be lower than previously estimated. Am. J. Gastroenterol.1999; 94(7): 1834-40

27. Javed M, Amin K, Muhammad D,et al. Prevalence of $H$. Pylori. Professional Med. J. 2010; 17 (3): 431-439.

28.Lee SW, Chang CS, Lee TY, et al. Risk factors and therapeutic response in Chinese patients with peptic ulcer disease. World J. Gastroenterol .2010; 16 (16): 2017-2022.

\section{Source of Support: Nil.}

Conflict of Interest: None Declared.

Copyright: ( ) the author(s) and publisher. IJMRP is an official publication of Ibn Sina Academy of Medieval Medicine \& Sciences, registered in 2001 under Indian Trusts Act, 1882.

This is an open access article distributed under the terms of the Creative Commons Attribution Non-commercial License, which permits unrestricted non-commercial use, distribution, and reproduction in any medium, provided the original work is properly cited.

Cite this article as: Essmaa H. Gutef. Association of Peptic Ulcer Diseases with Helicobacter Pylori Infection in Iraqi Patients. Int J Med Res Prof. 2016; 2(3):243-45. 